\title{
Sterilization Regret Among Married Women in India: Implications for the Indian National Family Planning Program
}

CONTEXT: In India, female sterilization accounts for $66 \%$ of contraceptive use, and age at sterilization is declining. It is likely that some women regret having been sterilized, but data on the prevalence of, and the social and economic correlates of, regret at the national level are insufficient.

METHODS: Data for analysis came from 30,999 sterilized women aged 15-49 interviewed in the 2005-2006 Indian National Family Health Survey. Logistic regression analyses and Wald tests were used to identify the social and demographic characteristics associated with sterilization regret.

RESULTS: Nationally, 5\% of sterilized women aged 15-49 reported sterilization regret. Women sterilized at age 30 or older were less likely than women sterilized before age 25 to express regret (odds ratio, 0.8). Compared with women having only sons, those who had only daughters were more likely to express regret (1.3), while those having both sons and daughters were less likely to express regret (0.8). Women who had experienced child loss had higher odds of reporting regret than women who had not (for one child lost, 1.6; for two or more children lost, 2.0).

CONCLUSIONS: Given the large proportion of women undergoing sterilization, the potential numbers experiencing regret are considerable. If age at sterilization continues to decline, sterilization regret is likely to increase. Encouraging couples to delay sterilization and increasing the availability of highly effective reversible contraceptives are options that India may consider to avert sterilization regret.

International Perspectives on Sexual and Reproductive Health, 2012, 38(4): 187-195, doi: 10.1363/3818712

In 1952, India became the first country in the world to launch an official family planning program with the aim of reducing population growth. ${ }^{1}$ During the initial phase of the family planning program, the rhythm method was the only birth control method recommended by the government. Because of the high rates of failure for this method, in 1956 the government began to offer condoms, diaphragms and spermicidal jelly ${ }^{2}$ to couples free of charge through hospitals, health centers and birth control clinics, and this "clinic approach" continued until the 1960s. In the 1960s, to further motivate couples to accept family planning, the government adopted an "extension approach," and the IUD and vaginal foam tablets were introduced. This new approach included an educational component designed to bring about changes in the knowledge, attitudes and behavior of people in regard to family planning. Male and female sterilization were introduced in 1966, and the government established method-specific targets for health workers to achieve. ${ }^{3}$ To accelerate the pace of fertility decline, the government introduced cash incentives to attract sterilization acceptors in 1967. During the Indian Emergency (1975-1977), in response to the unprecedented population growth of the 1960s documented in the 1971 census report, aggressive sterilization camps were held all over the country and about 8.3 million sterilizations were carried out. However, approximately $75 \%$ of the procedures were vascetomies. 3,4
A new family planning agenda focusing on voluntary acceptance of family planning evolved in the 1980s following the political fallout over the coercive sterilization program of the Emergency. ${ }^{4}$ During this era, method acceptance shifted from male sterilization to female sterilization. This shift is largely explained by the development of laparoscopic techniques for female sterilization; misconceptions and concerns about the side effects of vasectomy, such as loss of strength and libido; and the development of women-centered programs, such as the Reproductive and Child Health program..$^{5}$ Also driving the change was the 1991 implementation of a centrally sponsored incentive scheme to encourage eligible men and women to accept sterilization. According to this scheme, women undergoing tubectomy were eligible to receive 300 rupees (Rs.) and men undergoing vasectomy were eligible to get Rs. $200{ }^{6}$ This was revised in 2006, and women opting for sterilization were eligible for Rs. 600 and men undergoing vasectomy were eligible for Rs. 1,100, to compensate for wages lost during recovery. ${ }^{7}$ However, these amounts are flexible; state governments could pay as little as Rs. 150 to a sterilization acceptor.

Although method-specific contraceptive targets were removed in $1996,{ }^{2}$ the dominance of female sterilization in India's family planning program is reflected in numerous national surveys. According to the most recent National Family Health Survey (NFHS), carried out in 2005-2006,

\section{By Abhishek Singh, Reuben Ogollah, Faujdar Ram and Saseendran Pallikadavath}

Abhishek Singh is Leverhulme Fellow, Reuben Ogollah is lecturer, and Saseendran Pallikadavath is senior lecturer, all in the Global Health and Social Care Unit, School of Health Sciences and Social Work, University of Portsmouth, United Kingdom. Faujdar Ram is director and senior professor, International Institute for Population Sciences, Mumbai. 
about $37 \%$ of currently married women were female sterilization adopters, compared with 34\% in the 1998-1999 NFHS and 27\% in the 1992-1993 NFHS. ${ }^{8}$ Thus, there has been a steady increase in the percentage of women adopting sterilization in India. In 2005-2006, the country's contraceptive prevalence was $56 \%$, and $66 \%$ of users reported female sterilization as their method. ${ }^{8}$ The percentage of couples relying on male sterilization during the same period remained substantially lower than that of couples relying on female sterilization. For example, in 2005-2006, the percentage using male sterilization was 3\%, compared with 2\% in 1998-1999 and 4\% in 1992-1993.

Furthermore, use of female sterilization varies widely across states. For example, in Uttar Pradesh, one of the most economically and socially underdeveloped states in India, only about $17 \%$ of women were sterilization users in 2005-2006, compared with 63\% in the more developed and urbanized state of Andhra Pradesh. ${ }^{8}$ Although there are no targets for sterilization in the current program and acceptance of the method is voluntary, confusion and ambiguity about targets remain, and there are still cases of clients being lured with huge incentives for undergoing sterilization in some states. ${ }^{9-11}$

The current fertility norm in India is two or three children. ${ }^{8}$ Women are encouraged to marry early and complete childbearing soon thereafter. Typically, women are sterilized once they have achieved their desired family size. ${ }^{12}$ Thus, sterilization tends to occur relatively early, and age at sterilization is declining significantly in some states. For example, the median age at sterilization in India declined from 27 years in 1992-1993 to 25 years in 2005-2006. Further, in 2005-2006, about 81\% of women reported being sterilized before age $30 .{ }^{8}$ The median age at female sterilization was particularly low in Andhra Pradesh (23.3 years), Karnataka (23.9 years) and Tamil Nadu (24.9 years) in 2005-2006; these are states that have the lowest fertility rates in the country, as well as the strongest political will for population stabilization. ${ }^{8}$ In addition to desired family size norms, social norms also influence early acceptance of sterilization in India. Young women, particularly in Andhra Pradesh, adopt early sterilization to enhance their social status with their mothers-in-law. ${ }^{13}$ Furthermore, men make the decision about who should undergo sterilization; invariably it is women who do so. ${ }^{14}$

A potential consequence of low fertility and early age at sterilization is sterilization regret. Studies that have measured sterilization regret in various countries estimate its prevalence at around 10\% among sterilized women. ${ }^{15-19}$ In Brazil, a country with high sterilization rates, sterilization regret was found among $10-20 \%$ of sterilized women. ${ }^{20-23}$ Although female sterilization is more common in developing than in developed countries, the majority of studies on sterilization regret have been carried out in developed countries or in countries in which female sterilization is not the dominant family planning method. ${ }^{16,17,19,24-27}$

Studies have also investigated the characteristics associated with sterilization regret, including age at sterilization, number and sex of children, and experience of child loss. Women who are sterilized at a younger age are more likely to report sterilization regret than those sterilized at older ages. ${ }^{23,24,28-31}$ Compared with women who have more children, those with fewer children at the time of sterilization are more likely to experience regret. ${ }^{23,25,31}$ Similarly, women who have only male children are less likely to report sterilization regret than women who have only female children. ${ }^{26,31}$ Further, women who report having experienced child loss are more likely to report sterilization regret than women without such losses. ${ }^{15,26,27,32-34}$

Several family planning service characteristics have been associated with sterilization regret, including quality of follow-up after the procedure and women's involvement in decision making about their sterilization. Women who receive low-quality follow-up services after sterilization are more likely to report regret than those who receive better follow-up services. ${ }^{15,25,35,36}$ Regret is less common among women who are involved in making the decision about their sterilization than among those who are not involved. 29,31,32,34

A number of studies have examined the social characteristics associated with sterilization regret. Women who have less than a high school education are more likely to report regret than women with more education. ${ }^{28}$ Women who participate in the labor force are less likely than those who do not to regret sterilization. ${ }^{28}$ And finally, compared with those who are currently married, women who report being separated or divorced are more likely to experience sterilization regret. ${ }^{18,22,25,26,32-34,37,38}$

Research on sterilization regret in India is limited. The few studies conducted in India have either focused on a limited number of states or have been localized studies using small sample sizes, ${ }^{15,30,31,35}$ no studies have examined sterilization regret using a nationally representative data set. Given this context, the overall objective of this article is to examine sterilization regret in India and its associated variables relevant to the national family planning program. We hypothesize that sterilization regret will be independently associated with age at sterilization, number of years since sterilization, sex composition of children, experience of child loss and living in a community where low fertility is the norm. We hypothesize that older age at sterilization will be negatively associated with sterilization regret, whereas greater time since sterilization and the experience of child loss will be positively associated with regret. We further hypothesize that women having only daughters will be more likely to have regrets than women having only sons or a mix of sons and daughters. Finally, we hypothesize that women residing in communities where low fertility is the norm, such as Andhra Pradesh, Karnataka, Kerala and Tamil Nadu in the Southern region of the country, will be more likely to have sterilization regret than women residing in other communities.

As there are significant regional variations in sterilization acceptance in India, our study examined the above hypotheses according to geographic regions. It is impor- 
tant to examine the hypotheses separately for geographic regions because some of the factors affecting sterilization regret vary significantly across regions. For example, son preference is very strong in the Central and Northern regions of India, but is negligible in the Southern region. Similarly, child loss varies considerably across regions, and there is evidence of significant differences in age at sterilization. Also, because the variables that are associated with sterilization regret might depend on the length of time since the sterilization procedure occurred, the study examines the association between sterilization regret and the other variables separately for two groups of women-those sterilized in the five years preceding the survey and those who were sterilized six or more years earlier. The cut-off of six years was used to distinguish more recent sterilizations from those that had occurred further in the past. We hypothesize that the association between the sex composition of children and sterilization regret will be influenced by whether the sterilization was obtained in the recent past or whether it was obtained much earlier.

\section{METHODS}

Data

The present study uses data from the third round of the Indian NFHS, conducted in 2005-2006. The NFHS is a nationally representative, large-scale, cross-sectional, repeated household survey. The principal objective of the NFHS is to provide state- and national-level estimates on fertility, mortality and family planning. ${ }^{8}$ The survey adopted a twostage sampling design in most rural areas and a three-stage sampling design in most urban areas. In rural areas, the villages were selected at the first stage using a probability proportional to size sampling scheme. Then, the required number of households were selected at the second stage using systematic sampling. In urban areas, wards were selected at the first stage; at the second stage, census enumeration blocks-each containing approximately 150-200 households-were selected, and at the third stage, the required number of households were selected using systematic sampling technique. ${ }^{8}$ In the 2005-2006 round, the NFHS collected information from 109,041 households and 124,385 women aged 15-49 years; detailed information on the survey design and methods have been published elsewhere. ${ }^{8}$

Because the aim of the article is to investigate sterilization regret, the analysis is restricted to the 32,575 women who reported at the time of the survey that they had been sterilized. We excluded 1,549 women because information on sterilization regret was not available. As it is unusual for women in India to undergo sterilization without having had children, we also excluded 27 childless women who reported having been sterilized. This yielded a sample of 30,999 women for the analysis. *

*It is possible that the $\mathbf{2 7}$ women might have undergone sterilization for medical reasons. Ten women from this group reported regret for undergoing sterilization. However, as this group of women represented only $0.08 \%$ of the sample, the findings will not be affected by their exclusion

\section{Variables}

- Outcome variable. The outcome variable of interest is sterilization regret. All sterilized women were asked "Do you regret that you had the sterilization?" The response categories were "yes" or "no."

-Independent variables. The independent variables examined in the analysis were selected on the basis of earlier studies on sterilization regret conducted in similar socioeconomic settings and include age at sterilization (younger than 25, 25-29, 30 or older), years since sterilization (less than two years, 2-5 years, 6-10 years, more than 10 years) sex composition of children (only sons, only daughters, both sons and daughters), experience of child loss (no loss, one loss, two or more losses) and region of residence (North, Central, East, Northeast, West, South). Studies have clearly demonstrated an association between sterilization regret and age at sterilization, number of years since sterilization and experience of child loss. In addition, son preference has been shown to be an important predictor of contraceptive use and fertility in India, ${ }^{39-41}$ therefore, we included sex composition of children in the analysis. Region of residence was included in the analysis to account for geographic variance in fertility levels. The variables controlled for in the regression models are woman's education, woman's work status, parity at sterilization

\begin{tabular}{|c|c|c|}
\hline State & No.of women & $\%$ reporting regret \\
\hline \multicolumn{3}{|l|}{$\begin{array}{l}\text { ALL } \\
\text { India }\end{array}$} \\
\hline Rural & 21,216 & 4.7 \\
\hline Urban & 9,783 & 4.5 \\
\hline \multicolumn{3}{|l|}{ North } \\
\hline Jammu and Kashmir & 165 & 8.1 \\
\hline Himachal Pradesh & 215 & 2.2 \\
\hline Punjab & 583 & 2.6 \\
\hline Uttarakhand & 191 & 6.4 \\
\hline Haryana & 586 & 2.9 \\
\hline Rajasthan & 1,610 & 2.9 \\
\hline \multicolumn{3}{|l|}{ Central } \\
\hline Chhattisgarh & 755 & 3.1 \\
\hline Uttar Pradesh & 2,113 & 4.4 \\
\hline Madhya Pradesh & 2,305 & 3.6 \\
\hline \multicolumn{3}{|l|}{ East } \\
\hline Jharkhand & 529 & 7.7 \\
\hline Orissa & 907 & 6.5 \\
\hline Bihar & 1,604 & 4.7 \\
\hline West Bengal & 2,455 & 4.0 \\
\hline \multicolumn{3}{|l|}{ Northeast } \\
\hline Assam & 263 & 5.6 \\
\hline \multicolumn{3}{|l|}{ West } \\
\hline Gujarat & 1,772 & 5.1 \\
\hline Maharashtra & 3,910 & 3.1 \\
\hline \multicolumn{3}{|l|}{ South } \\
\hline Andhra Pradesh & 4,074 & 4.9 \\
\hline Karnataka & 2,807 & 7.7 \\
\hline Kerala & 1,148 & 7.0 \\
\hline Tamil Nadu & 2,639 & 3.3 \\
\hline
\end{tabular}


TABLE 2. Percentage of women reporting sterilization regret, by selected characteristics

Characteristic

No. $\quad$ Regret sterilization (\%)

Age at sterilization*

$<25$

$25-29$

$\geq 30$

14,035

10,886

5.0

4.4

Years since sterilization*

$<2$

$2-5$

$6-10$

$>10$

3,406

6,824

6,783

13,986

Sex composition of children*

Only sons

Only daughters

Both sons and daughters

22,740

8.4
4.0

Experience of child loss*

Noloss

23,573

5,352

4.1

1 loss

2,074

5.8
6.1

Region of residence*

North

3,556

5,173

5,496

395

5,711

10,668

3.6

5.0
4.7

East

Northeas

South

15,531

5,654

9,811

4.5

Woman's education

None

Primary

$\geq$ secondary

14,586

Not working

Working

16,384

4.6

Parity at sterilization

1

$2-3$

$\geq 4$

Caste

Scheduled castes

Scheduled tribes

5,980

2,389

13,001

8,639

4.4

Other backward classes

Other

26,987

2,327
1,654

4.4

Hindu

Muslim

6.5
4.5

Wealth quintiles

Poorest

Poorer

Middle

Richer

4,557

6,145

6,990

7,295

6,012

4.4

4.4

4.6

Richest

21,216

9,783

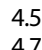

Urban

e more children after sterilization

No

10,215

20,781

4.2

4.8

*Bivariate associations were significant at $p<.05$. Notes: Ns are weighted and may not add to 30,999 because of missing cases.
(1, 2-3, 4 or more), caste, religion, wealth status of household (by quintile), place of residence (urban, rural) and whether the woman was informed before the sterilization procedure that she would not be able to have children afterward.

\section{Analysis}

We compared sterilization regret across the categories of the five independent variables in bivariate analysis. Chisquare tests and binary logistic regression were used to compare the significance of differences in sterilization regret across the categories of each independent variable. We then ran a multiple logistic regression model on the whole sample to estimate the adjusted effects of the independent variables on sterilization regret; control variables were also included in this model. All independent variables, particularly age at sterilization and number of years since sterilization, were tested for possible multicollinearity before they were added to the logistic regression models. Separate Wald tests were performed to determine whether the independent variables were associated with sterilization regret. To undertake separate regional level analyses, Indian states were grouped into six broad geographic regions-North, Central, East, Northeast, West and South-following the NFHS 2005-2006 classifications. ${ }^{8}$ Finally, the total sample was stratified into two groups-one comprising women who had undergone sterilization in the last five years and another comprising those who had undergone sterilization six or more years earlier. We carried out separate logistic regression analyses for the two groups to gain a greater understanding of the associations between the independent variables and the outcome variable.

\section{RESULTS}

In India, nearly 5\% of the sterilized women aged 15-49 in 2005-2006 reported sterilization regret (Table 1, page 189). The level of regret was highest in Jammu and Kashmir, Jharkhand and Karnataka ( $8 \%$ each), with Kerala (7\%), Orissa (7\%) and Uttarakhand 6\%) not far behind. The lowest level of regret was found in Himachal Pradesh (2\%). Among the smaller Northeastern states, sterilization regret was between $9 \%$ and $20 \%$ (not shown). Sterilization regret did not vary by urban-rural residence.

Sterilization regret varied considerably across the categories of the variables of interest (Table 2). The level of sterilization regret varied significantly by age at sterilization, years since sterilization, sex composition of children, experience of child loss and region of residence.

\section{Multivariate Findings}

Women who had been sterilized at age 30 or older had lower odds of reporting sterilization regret than women who had been sterilized before age 25 (odds ratio, 0.8-Table 3 ). Number of years since sterilization was positively associated with regret: Women sterilized 6-10 years or more than 10 years before the survey were more likely than re- 
cently sterilized women to report regret (1.3 for each). Sex composition of children was also independently associated with sterilization regret. Women who had only daughters were more likely than women having only sons to report sterilization regret (1.3). Interestingly, women who had both sons and daughters were significantly less likely to experience regret than were women who had only sons (0.8). Another variable that was independently and positively associated with sterilization regret was child loss. Women who had experienced one or two or more child losses had odds of reporting sterilization regret that were 1.6 and 2.0 times, respectively, those of women who did not experience any child losses. Compared with women residing in the South region, those residing in the North, Central and West regions were less likely to experience regret (0.7 for each). The odds of reporting sterilization regret were higher in the Northeast region than in the South region (2.0).

Wald test results provided statistical evidence supporting three of the five hypotheses proposed in the study. The findings suggest that sex composition of children and experience of child loss were independently associated with sterilization regret. Living in regions that have low fertility was also independently associated with sterilization regret. However, according to the results of the Wald test, age at sterilization and number of years since sterilization were not associated with sterilization regret.

In a multivariate regression analysis by geographic location, child loss was positively associated with sterilization regret in all six regions of India (Table 4, page 192). Overall, sterilized women who had experienced child loss were more likely than those who had not to regret sterilization (odds ratio, 1.5-2.3). In the West region, all women with two or more years since sterilization had elevated odds of reporting regret compared with women with less than two years since the procedure (2.5-2.6). The results related to sex composition of children were particularly interesting. Women having both sons and daughters in the North and South regions were less likely to regret sterilization than women in these regions who had only sons ( 0.7 for both). Sterilized women having only daughters in the West region were more likely to experience regret than women in that region who had only sons (2.0).

Among women who had undergone sterilization in the five years preceding the survey, the odds of sterilization regret were higher for those who had only daughters than for those having only sons (odds ratio, 1.5-Table 5, page 192). However, for those sterilized six or more years earlier, the odds of sterilization regret were significantly lower for women having both sons and daughters than for women having only sons (0.7). Sterilization regret was associated with child loss and region of residence regardless of length of time since sterilization.

\section{DISCUSSION}

Our study found that sterilization regret was independently associated with sex composition of children, experience of child loss and region of residence. Findings also
TABLE 3. Adjusted odds ratios (and 95\% confidence intervals) from logistic regressions identifying associations between sterilization regret and selected characteristics

Characteristic

Odds ratio

\section{Age at sterilization}

$<25$ (ref)

$25-29$

$\geq 30$

1.00

$0.94(0.83-1.05)$

$0.84(0.72-0.98)^{*}$

Years since sterilization

$<2$ (ref)

2-5

6-10

$>10$

Sex composition of childrent

Only sons (ref)

Only daughters

Both sons and daughters

\section{Experience of child losst}

No loss (ref)

1 loss

$\geq 2$ losses

1.00

$1.18(0.95-1.46)$

$1.31(1.05-1.61)^{*}$

$1.27(1.04-1.55)^{*}$

1.00

$1.28(1.06-1.56)^{*}$

$0.77(0.67-0.88)^{*}$

1.00

$1.58(1.37-1.83)^{*}$

$2.00(1.60-2.52)^{*}$

Region of residencet

South (ref)

1.00

North

Central

East

Northeast

West

$0.69(0.57-0.83)^{*}$

$0.72(0.60-0.87)^{*}$

$1.05(0.88-1.25)$

$1.99(1.61-2.45)^{*}$

$0.72(0.61-0.87)^{*}$

CONTROL VARIABLES

Woman's education

None (ref)

Primary

zsecondary

1.00

$1.00(0.86-1.17)$

$1.11(0.96-1.28)$

Woman's work status

Not working (ref)

1.00

Working

$1.05(0.93-1.17)$

\section{Parity at sterilization}

1 (ref)

2-3

1.00

$\geq 4$

$0.72(0.50-1.04)$

$0.55(0.37-0.82)^{*}$

\section{Caste}

Scheduled castes (ref)

Scheduled tribes

Other backward classes

Other

1.00

$1.26(1.02-1.55)^{*}$

$0.94(0.81-1.10)$

$0.91(0.77-1.07)$

\section{Religion}

Hindu (ref)

Muslim

1.00

Other

Wealth quintiles

Poorest (ref)

Poorer

Middle

Richer

Richest

\section{Place of residence}

Urban (ref)

Rural

1.00

$1.09(0.96-1.24)$

Woman informed that she cannot have more children after sterilization

No (ref)

1.00

Yes

$1.08(0.97-1.22)$ 
TABLE 4. Adjusted odds ratios (and 95\% confidence intervals) from logistic regression identifying associations between sterilization regret and selected characteristics, by geographic region

\begin{tabular}{|c|c|c|c|c|c|c|}
\hline Characteristic & $\begin{array}{l}\text { North } \\
(\mathrm{N}=3,556)\end{array}$ & $\begin{array}{l}\text { Central } \\
(\mathrm{N}=5,173)\end{array}$ & $\begin{array}{l}\text { East } \\
(\mathrm{N}=5,496)\end{array}$ & $\begin{array}{l}\text { Northeast } \\
(\mathrm{N}=395)\end{array}$ & $\begin{array}{l}\text { West } \\
(\mathrm{N}=5,711)\end{array}$ & $\begin{array}{l}\text { South } \\
(N=10,668)\end{array}$ \\
\hline \multicolumn{7}{|c|}{ Age at sterilization } \\
\hline$<25$ (ref) & 1.00 & 1.00 & 1.00 & 1.00 & 1.00 & 1.00 \\
\hline $25-29$ & $1.00(0.70-1.46)$ & $0.97(0.67-1.40)$ & $0.85(0.60-1.19)$ & $0.87(0.62-1.24)$ & $1.04(0.74-1.47)$ & $0.91(0.74-1.11)$ \\
\hline$\geq 30$ & $1.12(0.72-1.74)$ & $0.93(0.61-1.43)$ & $0.74(0.48-1.14)$ & $0.68(0.46-1.00)$ & $0.96(0.61-1.51)$ & $0.73(0.54-1.00)$ \\
\hline \multicolumn{7}{|c|}{ Years since sterilization } \\
\hline$<2$ (ref) & 1.00 & 1.00 & 1.00 & 1.00 & 1.00 & 1.00 \\
\hline $2-5$ & $0.84(0.46-1.54)$ & $0.81(0.45-1.48)$ & $1.52(0.83-2.78)$ & $1.10(0.66-1.84)$ & $2.46(1.13-5.35)^{*}$ & $1.12(0.78-1.62)$ \\
\hline $6-10$ & $1.05(0.59-1.88)$ & $1.53(0.88-2.68)$ & $1.37(0.75-2.52)$ & $0.94(0.56-1.57)$ & $2.62(1.21-5.67)^{*}$ & $1.32(0.92-1.90)$ \\
\hline$>10$ & $1.21(0.71-2.06)$ & $1.46(0.85-2.49)$ & $1.40(0.79-2.48)$ & $1.02(0.63-1.66)$ & $2.57(1.22-5.42)^{*}$ & $1.14(0.81-1.60)$ \\
\hline \multicolumn{7}{|c|}{ Sex composition of children } \\
\hline Only sons (ref) & 1.00 & 1.00 & 1.00 & 1.00 & 1.00 & 1.00 \\
\hline Only daughters & $1.57(0.64-3.88) \dagger$ & $1.85(0.90-3.80)$ & $1.57(0.89-2.80)$ & $1.02(0.57-1.82)$ & $2.03(1.13-3.64)^{*}, \dagger$ & $1.13(0.86-1.49) \dagger$ \\
\hline $\begin{array}{l}\text { Both sons and } \\
\text { daughters }\end{array}$ & $0.68(0.47-0.99)^{*}$ & $0.85(0.57-1.27)$ & $0.91(0.63-1.32)$ & $0.85(0.59-1.23)$ & $0.75(0.52-1.08)$ & $0.69(0.58-0.86)^{*}$ \\
\hline \multicolumn{7}{|c|}{ Experience of child loss } \\
\hline Noloss (ref) & 1.00 & 1.00 & 1.00 & 1.00 & 1.00 & 1.00 \\
\hline 1 loss & $1.31(0.85-2.03) \dagger$ & $1.43(0.97-2.10) \dagger$ & $1.53(1.04-2.25)^{*}$ & $1.73(1.17-2.55)^{*}, \dagger$ & $2.28(1.53-3.40)^{*}, \dagger$ & $1.50(1.16-1.94)^{*}, \dagger$ \\
\hline$\geq 2$ losses & $2.09(1.17-3.75)^{*}$ & $2.22(1.39-3.54)^{*}$ & $1.69(0.93-3.07)$ & $2.27(1.21-4.28)^{*}$ & $2.20(1.05-4.63)^{*}$ & $1.66(1.01-2.75)^{*}$ \\
\hline
\end{tabular}

${ }^{*} \mathrm{p}<$.05. Whald test was significant at $\mathrm{p}<$.05. Notes: Models controlled for woman's education, woman's work status, parity at sterilization, caste, religion, wealth status, place of residence and whether the woman was informed before sterilization that she would not be able to have any more children. ref=reference category.

revealed that women who had been sterilized at age 30 or older had lower odds of reporting sterilization regret than women who had been sterilized before age 25. We focus here on the variables with importance for family planning program policies. The finding on age at sterilization is consistent with the results of other studies conducted in various countries. ${ }^{19,23,24,28-30,32,34,37}$ As age at sterilization declines, sterilization regret is likely to increase in India. This is particularly important in such states as Andhra Pradesh, where median age at sterilization is already very low; it was 23 years in 2006-2007. Encouraging couples to delay ster-

TABLE 5. Adjusted odds ratios (and 95\% confidence intervals) from logistic regressions identifying associations between sterilization regret and selected characteristics, by number of years since sterilization

\begin{tabular}{|c|c|c|}
\hline Characteristic & $\begin{array}{l}\leq 5 \text { years } \\
(N=10,230)\end{array}$ & $\begin{array}{l}\geq 6 \text { years } \\
(\mathrm{N}=20,769)\end{array}$ \\
\hline \multicolumn{3}{|c|}{ Sex composition of childrent } \\
\hline Only sons (ref) & 1.00 & 1.00 \\
\hline Only daughters & $1.49(1.05-2.12)^{*}$ & $1.18(0.93-1.49)$ \\
\hline Both sons and daughters & $0.85(0.66-1.10)$ & $0.74(0.63-0.86)^{*}$ \\
\hline \multicolumn{3}{|l|}{ Experience of child loss $†$} \\
\hline Noloss (ref) & 1.00 & 1.00 \\
\hline 1 loss & $1.53(1.15-2.05)^{*}$ & $1.60(1.35-1.90)^{*}$ \\
\hline$\geq 2$ losses & $1.80(1.12-2.89)^{*}$ & $2.06(1.59-2.66)^{*}$ \\
\hline \multicolumn{3}{|l|}{ Region of residencet } \\
\hline South (ref) & 1.00 & 1.00 \\
\hline North & $0.63(0.44-0.91)^{*}$ & $0.70(0.56-0.87)^{*}$ \\
\hline Central & $0.52(0.36-0.74)^{*}$ & $0.81(0.66-1.00)$ \\
\hline East & $1.09(0.78-1.51)$ & $1.02(0.82-1.26)$ \\
\hline Northeast & $2.20(1.50-3.23)^{*}$ & $1.83(1.43-2.35)^{*}$ \\
\hline West & $0.68(0.48-0.96)^{*}$ & $0.73(0.59-0.90)^{*}$ \\
\hline
\end{tabular}

${ }^{*} \mathrm{p}<$.05. +Wald test was significant at $\mathrm{p}<.05$. Notes: Models controlled for woman's education, woman's work status, parity at sterilization, caste, religion, wealth status, place of residence and whether the woman was informed before sterilization that she would not be able to have any more children. ref=reference category. ilization is an important option that India may consider to avert sterilization regret.

A key finding of the study relates to the sex composition of living children. Results suggest that women who had only daughters were more likely to report regret than women who had only sons. Interestingly, women who had both sons and daughters were less likely to report regret than women who had only sons. Among women who had recent sterilizations, the odds of experiencing regret were higher among women having only daughters than among those having only sons. And among women who had undergone sterilizations six or more years earlier, the odds of reporting sterilization regret were elevated among those who had only sons compared with those who had a combination of sons and daughters. This is consistent with the findings of several other studies carried out in India that demonstrate the desire of Indian women to have both sons and daughters. Indian women perceive that while sons may take care of their economic needs, daughters will look after them when they are old. ${ }^{42}$

As reported in a number of studies, women who experienced child loss were more likely to regret sterilization than those who did not. This finding is important for two reasons. First, fertility is declining in India and many states have already achieved below-replacement fertility. ${ }^{8}$ Second, recent trends in infant mortality rates indicate that the declines in infant mortality have stagnated at unacceptably high levels in the majority of states in the country. ${ }^{43}$ The infant mortality rate in India was around 57 per 100,000 live births in 2005-2006, and ranged from as low as 15 in Kerala to as high as 73 in Uttar Pradesh. ${ }^{8}$ It is the same in the case of child mortality. Very low levels of fertility and high infant and child mortality seem to be an important context for sterilization regret as women may experience 
the death of their offspring after undergoing sterilization. Reversal operations to resume child bearing are not currently offered in the public health care system in India. Because these are available only through private providers, and involve huge costs, the poor do not have the resources to reverse sterilization. It is important to mention here that in Brazil, a country that has among the highest rates of sterilization and sterilization regret, a law was passed in 1997 prohibiting men and women from undergoing sterilization before they have had at least two children. ${ }^{44,45}$

Another key finding of the study relates to region of residence. Results adjusted for socioeconomic and demographic characteristics clearly indicate that women residing in regions marked by low fertility are more likely to regret sterilization than women residing in regions with high fertility. For example, women residing in high fertility regions such as the North, Central, and West regions were significantly less likely to report sterilization regret than women residing in the South region, where fertility is very close to replacement level. It is possible that women in the South region are undergoing sterilization with fewer children to conform to the existing social norm rather than to their personal circumstances. The Northeast region was an exception to the pattern-the level of regret was higher there than in the South region even though fertility is higher in the Northeast; however, age at sterilization is also higher in the Northeast region than in the South.

In many societies, divorce and separation are associated with sterilization regret. ${ }^{18,22,25,26,32,34,37,38}$ However, in this study, it was not possible to include divorced and separated women in the analysis because the numbers of such women were too low. In India, traditionally, divorce and separation have been uncommon because of the importance given to the institution of family, where women and men are often forced to remain in union. However, recent studies have noted an increase in divorce and separation rates, particularly among women younger than $35 .{ }^{46,47} \mathrm{Fe}-$ male sterilization could affect a woman's ability to remarry if a prospective husband wanted to have children.

Potential limitations of the study should be noted. First, we could not examine sterilization regret associated with male sterilization because of data limitations; the information on sterilization regret in the NFHS was sought only in the case of female sterilization. Second, we could not include divorced, separated and widowed women in the multivariate analyses because the numbers of women in these categories were very small. Third, we could not control for quality of sterilization services because such information was not available in the data set. Fourth, there were no specific questions related to the reasons leading to sterilization regret in the 2005-2006 NFHS; consequently, we could not examine the specific reasons for sterilization regret. Another point worth mentioning is that we could not differentiate between child loss before and after sterilization because of data limitations. This should not influence our findings because there is no reason to believe that women will regret sterilization when child loss occurs before sterilization; these women would still have the opportunity to have more children. Finally, we could not externally validate the information on sterilization regret provided by the respondents. However, it should be noted that the survey format has been regularly used in the various rounds of the NFHS and the findings are widely used to monitor the performance of policies and programs in India. ${ }^{48}$ Survey teams receive formal training and quality control measures are in place.

\section{CONCLUSIONS}

In India, nearly $5 \%$ of sterilized women reported regret and there were significant interstate and interregional variations. Recent estimates released by India's Ministry of Health and Family Welfare has put the number of couples annually adopting sterilization at close to two million. The estimates also show no change in sterilization use in the country over the past few years. ${ }^{49}$ Simple calculation indicates that if even $5 \%$ of sterilized women have regrets, that will translate to around 100,000 women annually.

The findings of our study suggest that, before adopting sterilization, many couples would benefit from an opportunity to reexamine what their fertility desires might be should their circumstances change. This conclusion leads to a number of implications for the Indian family planning program. First, India should be more focused on providing a good mix of family planning methods, particularly to younger couples. Bangladesh might provide an example of a good alternative future course for India-sterilization in Bangladesh declined dramatically with the enhanced provision of reversible methods of family planning. ${ }^{12}$ Second, family planning programs should discourage sterilization among couples with only one child and should focus on providing temporary methods of family planning so that they can resume childbearing if they desire. Third, concerted efforts must be made to reduce the levels of infant and child mortality in India. Finally, although we found no significant difference in levels of regret between women who were informed about the irreversibility of sterilization and those who were not, our data show that about one-third of women were not informed. All women should be given this information before they decide on such an important step. India could also consider discouraging postpartum sterilizations (as is the case in Brazil and many other countries), as the process of delivery and the hospital environment might influence women to undergo sterilization.

\section{REFERENCES}

1. Ledbetter R, Thirty years of family planning in India, Asian Survey, 1984, 24(7):736-758.

2. Srinivasan K, Population policies and programmes since independence: a saga of great expectations and poor performances, Demography India, 1998, 27(1):1-22.

3. Gwatkin DR, Political will and family planning: the implications of India's emergency experience, Population and Development Review, 1979, 5(1):29-59.

4. Basu AM, Family planning and the emergency: an unanticipated consequence, Economic and Political Weekly, 1985, 20(10):422-425. 
5. National Population Stabilization Fund, Why is it that fewer couples opt for male sterilization? 2007, <http://www.jsk.gov.in/faq asp\#b24>, accessed Apr. 23, 2012

6. Government of India, Manual for Family Planning Insurance Scheme (To Be Operated by Oriental Insurance Company), New Delhi: Ministry of Health and Family Welfare (MOHFW), 2005, <http://mohfw. nic.in/WriteReadData/1892s/FPIS\%202005\%20manual-15916277. pdf>, accessed Apr. 23, 2012.

7. Government of India, Manual for Family Planning Insurance Scheme: Implemented Through ICICI Lombard General Insurance Company, New Delhi: MOHFW, 2011, <http://mohfw.nic.in/WriteReadData/1892s/ FPIS\%20Manual\%202011-36994846.pdf>, accessed Apr. 23, 2012.

8. International Institute for Population Sciences (IIPS) and Macro International, National Family Health Survey (NFHS-3), 2005-06: India, Vol. 1, Mumbai: IIPS, 2007.

9. MP CM lauds Sanjay Gandhi's sterilisation drive, Deccan Herald, Aug. 28, 2011, <http://www.deccanherald.com/content/92285/mpcm-lauds-sanjay-gandhis.html>, accessed May 7, 2012.

10. India: Rajasthan in 'cars for sterilisation' drive, BBC News South Asia, July 1, 2011, <http://www.bbc.co.uk/news/world-southasia-13982031>, accessed May 7, 2012.

11. Sangwan N and Maru M, The target-free approach: an overview, Journal of Health Management, 1999, 1(1):71-96.

12. Matthews $Z$ et al., Does early childbearing and a sterilizationfocused family planning programme in India fuel population growth? Demographic Research, 2009, 20(28):693-720.

13. Säävälä M, Understanding the prevalence of female sterilization in rural south India, Studies in Family Planning, 1999, 30(4):288-301.

14. Krithika BK, Men say no to sterilization despite lower health risks, Daily Observer, Dec. 8, 2011, <http://www.iijnm.org/media uploads/observer/2011_12/issue17/issue17.pdf>, accessed Apr. 23, 2012.

15. Ramanathan M and Mishra US, Correlates of female sterilization regret in the southern states of India, Journal of Biosocial Science, 2000, 32(4):547-558

16. Henshaw SK and Singh S, Sterilization regret among U.S. couples, Family Planning Perspectives, 1986, 18(5):238-240.

17. Marcil-Gratton N, Sterilization regret among women in metropolitan Montreal, Family Planning Perspectives, 1988, 20(5):222-227.

18. Vieira EM and Ford NJ, Regret after female sterilization among low-income women in Sao Paulo, Brazil, International Family Planning Perspectives, 1996, 22(1):32-37 \& 40

19. Gray A, Regret after sterilization: can it be averted? Policy Dialogue, Dhaka, Bangladesh: Population Council, 1996, No. 4.

20. Rosenfeld BL et al., Sequelae of postpartum sterilization, Archives of Gynecology and Obstetrics, 1998, 261(4):183-187.

21. Hillis SD et al., Higher hysterectomy risk for sterilized than nonsterilized women: findings from the U.S. Collaborative Review of Sterilization, Obstetrics \& Gynecology, 1998, 91(2):241-246.

22. Nervo P et al., Regret after tubal sterilization, Journal de Gynécologie, Obstétrique et Biologie de la Reproduction, 2000, 29(5):485-491 (in French).

23. Schmidt JE et al., Requesting information about and obtaining reversal after tubal sterilization: findings from the U.S. Collaborative Review of Sterilization, Fertility and Sterility, 2000, 74(5):892-898.

24. Curtis KM, Mohllajee AP and Peterson HB, Regret following female sterilization at a young age: a systematic review, Contraception, 2006, 73(2):205-210.

25. Loaiza E, Sterilization regret in the Dominican Republic: looking for quality-of-care issues, Studies in Family Planning, 1995, 26(1):3948

26. Kim SH et al., Microsurgical reversal of tubal sterilization: a report on 1,118 cases, Fertility and Sterility, 1997, 68(5):865-870.
27. Hapugalle D et al., Sterilization regret in Sri Lanka: a retrospective study, International Family Planning Perspectives, 1989, 15(1):22-28.

28. McGonigle KF and Huggins GR, Tubal sterilization: epidemiology of regret, Contemporary Obstetrics and Gynecology, 1990, $35(10): 15-24$

29. Hardy E et al., Risk factors for tubal sterilization regret, detectable before surgery, Contraception, 1996, 54(3):159-162.

30. Jamieson DJ, Poststerilization regret: findings from India and the United States, Indian Journal of Medical Sciences, 2007, 61(6):359-360.

31. Malhotra N, Chanana C and Garg P, Post-sterilization regrets in Indian women, Indian Journal of Medical Sciences, 2007, 61(4):186-191.

32. Chi IC and Jones DB, Incidence, risk factors and prevention of poststerilization regret in women: an updated international review from an epidemiological perspective, Obstetrical \& Gynecological Survey, 1994, 49(10):722-732.

33. Machado KM, Ludermir AB and da Costa AM, Changes in family structure and regret following tubal sterilization, Cadernos de Saúde Pública, 2005, 21(6):1768-1777.

34. Ludermir $\mathrm{AB}$ et al., Tubal ligation regret and related risk factors: findings from a case-control study in Pernambuco State, Brazil, Cadernos de Saúde Pública, 2009, 25(6):1361-1368.

35. Zavier F and Nair SN, Regret after sterilisation: a sociodemographic analysis in south India, Demography India, 1998, 27(2):383-400

36. Zavier F and Padmadas SS, Use of a spacing method before sterilization among couples in Kerala, India, International Family Planning Perspectives, 2000, 26(1):29-35.

37. Platz-Christensen JJ et al., Evaluation of regret after tubal sterilization, International Journal of Gynaecology \& Obstetrics, 1992 , 38(3):223-226

38. Hillis SD et al., Poststerilization regret: findings from the United States Collaborative Review of Sterilization, Obstetrics \& Gynecology, 1999, 93(6):889-895

39. Arokiasamy P, Gender preference, contraceptive use and fertility in India: regional and development influences, International Journal of Population Geography, 2002, 8(1):49-67.

40. Arnold F, Choe MK and Roy TK, Son preference, the family building process and child mortality in India, Population Studies, 1998, 52(3):301-315

41. Mutharayappa R et al., Son preference and its effect on fertility in India, National Family Health Survey Subject Reports, Mumbai: IIPS, 1997, No. 3

42. Pallikadavath $S$ and Wilson $C$, A paradox within a paradox scheduled caste fertility in Kerala, Economic and Political Weekly, 2005, 40(28):3085-3093

43. Office of the Registrar General and Census Commissioner, India, Compendium of India's Fertility and Mortality Indicators, 1971-2007. New Delhi: Office of the Registrar General and Census Commissioner, India, 2010.

44. Potter JE et al., Inequities and policy dilemmas in the course of an unregulated, spontaneous fertility transition: the case of Brazil, paper presented at the International Union for the Scientific Study of Population (IUSSP) General Conference, Salvador de Bahia, Brazil, Aug. 18-24, 2001

45. Leone $\mathrm{T}$ and Padmadas SS, The proliferation of female sterilization in Brazil and India: a comparative analysis of the cohort and parity effects, Genus, 2007, 63(3/4):77-97.

46. DeSilva I, Demographic and Social Trends Affecting Families in the South and Central Asian Region, New York: Department of Economic and Social Affairs, Division for Social Policy and Development, Program on the Family, 2003

47. Singh AK and Sinha RK, Growing incidence of divorce in Indian cities: a study of Mumbai, paper presented at the IUSSP General Conference, Tours, France, July 18-23, 2005. 
48. MOHFW, Annual Report to the People on Health, New Delhi: MOHFW, 2010.

49. Dhar A, More couples adopting family planning measures, Hindu, Jan. 16, 2012, <http://www.thehindu.com/news/national/ article2804173.ece>, accessed Dec. 15, 2011.

\section{RESUMEN}

Contexto: En la India, la esterilización femenina representa el $66 \%$ del uso de anticonceptivos y la edad al momento de la esterilización está en descenso. Es probable que algunas mujeres se arrepientan de haber sido esterilizadas, pero los datos a nivel nacional sobre la prevalencia del arrepentimiento y los factores sociales y económicos correlacionados son insuficientes.

Métodos: Los datos para el análisis provinieron de entrevistas a 30,999 mujeres esterilizadas, en edades de 15-49 años, que tomaron parte en la National Family Health Survey 2005-2006 de la India. Se utilizaron análisis de regresión logística y pruebas Wald para identificar las características sociales y demográficas asociadas con el arrepentimiento de haberse sometido a la esterilización.

Resultados: A nivel nacional, el 5\% de las mujeres esterilizadas en edades de 15-49 años reportaron estar arrepentidas de su decisión de esterilizarse. Las mujeres que se sometieron a la operación a los 30 años o mayores, tuvieron menos probabilidad de expresar arrepentimiento que las mujeres que la hicieron antes de los 25 años (razón de momios, 0.8). En comparación con las mujeres que tenían solamente hijos varones, aquellas que tenian solamente hijas mujeres tuvieron mayor probabilidad de expresar arrepentimiento (1.3), mientras que aquellas que tenían tanto hijos como hijas tuvieron menos probabilidad de expresarlo (0.8). Las mujeres que habian sufrido la muerte de un hijo o hija tuvieron mayores probabilidades de reportar arrepentimiento que las mujeres que no lo experimentaron (para la pérdida de un hijo, razón de momios de 1.6; para la pérdida de dos o más hijos, 2.0).

Conclusiones: Ante la gran proporción de mujeres que se someten a la esterilización, las cifras potenciales de mujeres que expresan el arrepentimiento son considerables. Si la edad al momento de la esterilización continúa en descenso, es probable que aumente el arrepentimiento de haberse sometido al procedimiento. Alentar a las parejas a retrasar la esterilización y aumentar la disponibilidad de anticonceptivos reversibles altamente efectivos, son opciones que India puede considerar para evitar el arrepentimiento por la esterilización.

\section{RÉSUMÉ}

Contexte: En Inde, la stérilisation féminine représente 66\% de la pratique contraceptive et l'âge au moment de la procédure est en baisse. Certaines femmes regrettent vraisemblablement de s'être fait stériliser, mais les données de prévalence, de même que les corrélats socioéconomiques du regret sont insuffisants à l'échelle nationale.

Méthodes: Les données soumises à l'analyse sont celles relatives à 30.999 femmes de 15 à 49 ans stérilisées interviewées à l'occasion de l'Enquête nationale indienne 2005-2006 sur la santé familiale. Les caractéristiques sociodémographiques associées au regret de la stérilisation ont été identifiées par analyses de régression logistique et tests de Wald.

Résultats: À l'échelle nationale, 5\% des femmes stérilisées de 15 à 49 ans ont déclaré regretter leur choix. Les femmes stérilisées à l'âge de 30 ans ou au-delà sont moins susceptibles que celles stérilisées avant l'âge de 25 ans d'exprimer un regret (RC, 0,8). Par rapport aux femmes n'ayant que des fils, celles n'ayant que des filles sont plus susceptibles d'exprimer un regret (1,3), tandis que celles mères de fils et de filles le sont moins $(0,8)$. Les femmes ayant vécu la mort d'un enfant sont plus susceptibles d'exprimer un regret (en cas de perte d'un enfant, 1,6; après la perte de deux enfants ou plus, 2,0).

Conclusions: Étant donné l'importante proportion de femmes qui se soumettent à la stérilisation, le nombre potentiel de celles qui éprouvent un regret est considérable. Si l'âge au moment de la stérilisation continue de baisser, le taux de regret augmentera vraisemblablement. L'accroissement de l'âge pour la stérilisation est une option de politique que l'Inde pourrait envisager pour éviter le regret. Encourager les couples à différer la stérilisation et accroître la disponibilité de méthodes contraceptives réversibles hautement efficaces sont des options que l'Inde pourrait envisager pour éviter le regret.

\section{Acknowledgments}

This study was supported by a British Academy Research Development Award (grant BARDA-52798).

Authorcontact:abhi_iips@yahoo.co.in 